\title{
Identification of reference genes for quantitative PCR analyses in developing mouse gonads
}

\author{
Toshifumi YOKOYAMA ${ }^{1) *}$, Takuya OMOTEHARA ${ }^{1,2)}$, Tetsushi HIRANO ${ }^{1,3)}$, \\ Naoto KUBOTA ${ }^{1)}$, Shogo YANAI ${ }^{1)}$, Chinatsu HASEGAWA ${ }^{1)}$, Tadashi TAKADA ${ }^{1}$, \\ Yohei MANTANI ${ }^{1)}$ and Nobuhiko HOSHI ${ }^{1)}$ \\ ${ }^{1)}$ Department of Animal Science, Graduate School of Agricultural Science, Kobe University, \\ Kobe 657-8501, Japan \\ ${ }^{2)}$ Department of Anatomy, Tokyo Medical University, 6-1-1 Shinjuku, Shinjuku, Tokyo 160-8402, Japan \\ ${ }^{3)}$ Division of Drug and Structural Research, Life Science Research Center, University of Toyama, \\ 2630 Sugitani, Toyama 930-0194, Japan
}

J. Vet. Med. Sci.

80(10): 1534-1539, 2018

doi: 10.1292/jvms.18-0417

Received: 18 July 2018

Accepted: 23 August 2018

Published online in J-STAGE:

3 September 2018
ABSTRACT. Stable reference genes are important for gene expression analyses such as quantitative PCR. The stability of 15 candidate reference genes that can be used to developing mouse gonads was thoroughly verified using combinations of multiple algorithms. The expression of these genes fluctuated greatly depending on the analysis period and/or gender. Peptidylprolyl isomerase A (Ppia) and polymerase (RNA) II (DNA directed) polypeptide A (Polr2a) were the reference genes that were used stably for a wide analysis period in developing mouse gonads. Furthermore, the stable reference genes corresponding to the analysis period and/or gender were ranked. These results are useful for the selection of the optimal reference gene required for highprecision measurements.

KEY WORDS: developing mouse gonad, gene expression, normalization, quantitative PCR, reference gene

Testes in males (XY) and ovaries in females (XX) are the organs that generate gametes (germ cells). They arise from an undifferentiated bipotential gonad replies on the expression of the sex-determining region of the Y chromosome (SRY/Sry). In XY gonads that differentiate into testes, cell differentiation and proliferation occur under the influence of Sry-expressing Sertoli cells [15]. In this process, various kinds of genes are expressed in a specific spatiotemporal manner. As a result, the cell types in the gonad increase and their ratio change. Both expressed genes and developmental stages of germ cells differ in the gonads of males and females. Gene transfer and gene knockout methods in mice are important for elucidating these mechanisms. In particular, the C57BL/6 strain, which is referred to as a mouse reference sequence, is frequently used, and the expression of many genes has been measured [15]. In order to elucidate the developmental process of gonads, both histological methods to examine localization of expression and molecular biological methods to examine the expression level are essential.

Stably expressed genes called housekeeping genes, such as actin, beta (Actb), glyceraldehyde-3-phosphate dehydrogenase (Gapdh), and 18S ribosomal RNA (Rn18s), are commonly used to normalize mRNA expression levels between different samples in quantitative polymerase chain reaction (qPCR) studies $[4,11]$. Nucleic acids used for measurement include experimentally generated errors such as cell number, mRNA extraction degree, and transcription efficiency into complementary DNA (cDNA), and are normalized by dividing by the value of the stably expressed gene (reference gene). The expression levels of these genes may vary depending on cell type, tissue, gender, and developmental stage, and may change further under experimental conditions [11]. Adjusting the cell number or reverse-transcription efficiency using fluctuating genes produces large errors [19]. Therefore, the selection of reference genes is crucial for gene expression studies $[4,11]$. However, the information on stable reference genes in mouse gonads has been reported only at the early development stage (11.5-14.5 days post coitum (dpc)) [17] and at the postnatal stage (neonate to 5 months) [8].

Today algorithm-based ranking methods, such as geNorm (https://genorm.cmgg.be/) [21], NormFinder (https://moma.dk/ normfinder-software) [2], and BestKeeper (https://www.gene-quantification.de/bestkeeper.html) [13], are commonly used for the selection of reference genes. GeNorm repeats the procedure of eliminating the lowest stability gene, using the correlation of gene

*Correspondence to: Yokoyama, T.: tyokoyama@port.kobe-u.ac.jp

O2018 The Japanese Society of Veterinary Science

This is an open-access article distributed under the terms of the Creative Commons Attribution Non-Commercial No Derivatives (by-nc-nd) License. (CC-BY-NC-ND 4.0: https://creativecommons.org/licenses/by-nc-nd/4.0/) 
Table 1. Primer sequences for reference genes

\begin{tabular}{|c|c|c|c|c|c|}
\hline $\begin{array}{l}\text { Gene } \\
\text { symbol }\end{array}$ & $\begin{array}{l}\text { Accession } \\
\text { number }\end{array}$ & Gene name & Primers $\left(5^{\prime}-3^{\prime}\right)$ & $\begin{array}{l}\text { Size } \\
\text { (bp) }\end{array}$ & $\begin{array}{l}\text { References } \\
\text { of primer } \\
\text { sequences }\end{array}$ \\
\hline$A c t b$ & NM_007393 & Actin, beta & $\begin{array}{l}\text { F: CTAAGGCCAACCGTGAAAAG } \\
\text { R: ACCAGAGGCATACAGGGACA }\end{array}$ & 104 & [17] \\
\hline$B 2 m$ & NM_009735 & Beta-2 microglobulin & $\begin{array}{l}\text { F: TGCTACTCGGCGCTTCAGTC } \\
\text { R: AGGCGGGTGGAACTGTGTTAC }\end{array}$ & 200 & [9] \\
\hline Gapdh & NM_008084 & Glyceraldehyde-3-phosphate dehydrogenase & $\begin{array}{l}\text { F: CGTCCCGTAGACAAAATGGT } \\
\text { R: TTGATGGCAACAATCTCCAC }\end{array}$ & 110 & [17] \\
\hline Gusb & NM_010368 & Glucuronidase, beta & $\begin{array}{l}\text { F: CACGGCGATGGACCCAAGAT } \\
\text { R: CCCATTCACCCACACAACTGC }\end{array}$ & 86 & - \\
\hline Hprt & NM_013556 & Hypoxanthine guanine phosphoribosyl transferase & $\begin{array}{l}\text { F: AGGCCAGACTTTGTTGGATTTG } \\
\text { R: CTTAGGCTTTGTATTTGGCTTTTCC }\end{array}$ & 136 & - \\
\hline$P g k 1$ & NM_008828 & Phosphoglycerate kinase 1 & $\begin{array}{l}\text { F: CTGACTTTGGACAAGCTGGACG } \\
\text { R: GCAGCCTTGATCCTTTGGTTG }\end{array}$ & 110 & [22] \\
\hline Polr2a & NM_009089 & Polymerase (RNA) II (DNA directed) polypeptide A & $\begin{array}{l}\text { F: ATCAACAATCAGCTGCGGCG } \\
\text { R: GCCAGACTTCTGCATGGCAC }\end{array}$ & 144 & - \\
\hline Ppia & NM_008907 & Peptidylprolyl isomerase A & $\begin{array}{l}\text { F: CGCGTCTCCTTCGAGCTGTTTG } \\
\text { R: TGTAAAGTCACCACCCTGGCACAT }\end{array}$ & 150 & [22] \\
\hline$R n 18 s$ & NR_003278 & $18 \mathrm{~S}$ ribosomal RNA & $\begin{array}{l}\text { F: GATCCATTGGAGGGCAAGTCT } \\
\text { R: CCAAGATCCAACTACGAGCTTTTT }\end{array}$ & 103 & [17] \\
\hline Rplp0 & NM_007475 & Ribosomal protein, large $\mathrm{P} 0$ & $\begin{array}{l}\text { F: AGATTCGGGATATGCTGTTGGC } \\
\text { R: TCGGGTCCTAGACCAGTGTTC }\end{array}$ & 109 & [25] \\
\hline Sdha & NM_023281 & $\begin{array}{l}\text { Succinate dehydrogenase complex, subunit A, } \\
\text { flavoprotein }(\mathrm{Fp})\end{array}$ & $\begin{array}{l}\text { F: TGTTCAGTTCCACCCCACA } \\
\text { R: TCTCCACGACACCCTTCTGT }\end{array}$ & 66 & [17] \\
\hline$T b p$ & NM_013684 & TATA box binding protein & $\begin{array}{l}\text { F: GCTCTGGAATTGTACCGCAG } \\
\text { R: TGACTGCAGCAAATCGCTTG }\end{array}$ & 130 & - \\
\hline Tfre & NM_011638 & Transferrin receptor & $\begin{array}{l}\text { F: GGCGCTTCCTAGTACTCCCT } \\
\text { R: TCTGCAGCCAGTTTCATCTCCA }\end{array}$ & 162 & - \\
\hline$U b c$ & NM_019639 & Ubiquitin $\mathrm{C}$ & $\begin{array}{l}\text { F: AGGTCAAACAGGAAGACAGACGTA } \\
\text { R: TCACACCCAAGAACAAGCACA }\end{array}$ & 80 & [24] \\
\hline Ywhaz & NM_011740 & $\begin{array}{l}\text { Tyrosine 3-monooxygenase/tryptophan } \\
\text { 5-monooxygenase activation protein, zeta polypeptide }\end{array}$ & $\begin{array}{l}\text { F: TTGATCCCCAATGCTTCGC } \\
\text { R: CAGCAACCTCGGCCAAGTAA }\end{array}$ & 88 & [22] \\
\hline
\end{tabular}

expression [21]. NormFinder determines the stability of genes using intragroup and intergroup gene expression variance [2]. The feature of BestKeeper is to use the $\mathrm{Ct}$ (threshold cycle) value, and the stability is determined based on the variance of the cycle number [13]. However, because the results of each calculation algorithm are different from each other, it is difficult to decide which to adopt [11]. Several reports have merely described the results for each method [5, 14, 23], while other reports decided the final ranking from the arithmetic mean or geometric mean of ranks on each test $[3,18]$. In the present study, we calculated the stability of reference genes from three different algorithms and identified stable reference genes in the gonads from the undifferentiated to adult stages.

C57BL/6NCrSlc mice were purchased from SLC Japan (Hamamatsu, Japan) and maintained as described elsewhere [20]. Male and female mice or their fetuses were used at 10.5, 11.5, 12.5, 13.5, 14.5, 15.5, 16.5, 17.5, 18.5 dpc, neonate, 5-week-old, and adult (male: 39 weeks; female: 29 weeks). This study was approved by the Institutional Animal Care and Use Committee (Permission \#22-8-03) and carried out according to the Kobe University Animal Experimental Regulations.

The gonad-mesonephros complex (only at $10.5 \mathrm{dpc}$ ) or gonads were collected from three animals at each time point immediately after euthanasia, which was accomplished under deep anesthesia with isoflurane. Bilateral samples of each individual were collected and used together. Total RNA was extracted with the ReliaPrep RNA Cell Miniprep System (Promega, Madison, WI, U.S.A.), including on-column DNaseI treatment. For cDNA synthesis, a PrimeScript RT reagent Kit (Takara Bio, Kusatsu, Japan) with both random hexamer primers and oligo (dT) primers was used according to the manufacturer's procedures. The cDNA samples were diluted 10 times with EASY Dilution (Takara Bio) and divided into small amounts to avoid freeze-thaw cycles. Real-time PCR was performed on a Thermal Cycler Dice TP-860 system (Takara Bio) using SYBR Premix EX TaqII (Takara Bio). The cycling parameters were as follows: thermal activation for $10 \mathrm{sec}$ at $95^{\circ} \mathrm{C}$ and 50 cycles of PCR (melting for $5 \mathrm{sec}$ at $95^{\circ} \mathrm{C}$, annealing for $10 \mathrm{sec}$ at $60^{\circ} \mathrm{C}$, and extension for $120 \mathrm{sec}$ at $72^{\circ} \mathrm{C}$ ). The applied primers are listed in Table 1. Melting temperature analysis and electrophoresis of the PCR products were performed for each experiment to verify that only single products were amplified. The second derivative maximum method was used to determine the Cycle quantification. Each run was designed to 
Table 2. Ranking of candidate reference genes from each algorithm in the all-period

\begin{tabular}{|c|c|c|c|c|c|c|c|c|c|c|c|c|c|c|c|c|}
\hline Alg & & Ppia & olr $2 a$ & Rplp0 & Gusb & Hprt & $U b c$ & PgkI & Tfre & $B 2 m$ & Tbp & $A c t b$ & $n 18 s$ & Sdha & $n$ & Twhe \\
\hline B & & $\begin{array}{c}1 \\
(0.51)\end{array}$ & $\begin{array}{c}2 \\
(0.53)\end{array}$ & $\begin{array}{c}4 \\
0.75)\end{array}$ & $\begin{array}{c}3 \\
(0.74)\end{array}$ & $\begin{array}{c}8 \\
(0.93)\end{array}$ & $\begin{array}{c}7 \\
(0.87)\end{array}$ & $\begin{array}{c}6 \\
(0.84)\end{array}$ & $(0.84)$ & $\begin{array}{c}10 \\
(1.09)\end{array}$ & $\begin{array}{c}9 \\
(1.03)\end{array}$ & $\begin{array}{c}11 \\
(1.73)\end{array}$ & $\begin{array}{c}12 \\
(1.75)\end{array}$ & $\begin{array}{c}13 \\
(1.91)\end{array}$ & & $\begin{array}{l}15 \\
4.35)\end{array}$ \\
\hline & Ding & (0.81) & $(0.98)$ & $(0.87)$ & (1.06) & $(0.84)$ & (1.15) & $(1.05)$ & $(1.25)$ & (1.31) & & (1.48) & & (1.76) & & $(4.26)$ \\
\hline & Onty & & $(0.48)$ & $(0.59)$ & $\begin{array}{c}5 \\
(0.83)\end{array}$ & $\begin{array}{c}6 \\
(0.92)\end{array}$ & $(0.69)$ & $\begin{array}{c}8 \\
(1.05)\end{array}$ & (1.11) & $\begin{array}{c}7 \\
(0.99)\end{array}$ & $\begin{array}{c}10 \\
(1.16)\end{array}$ & $\begin{array}{c}11 \\
(1.29)\end{array}$ & $\begin{array}{c}12 \\
(1.45)\end{array}$ & $\begin{array}{c}13 \\
(1.58)\end{array}$ & $\begin{array}{c}14 \\
(1.89)\end{array}$ & $\begin{array}{c}15 \\
(2.23\end{array}$ \\
\hline G & mean & .1 & 2.2 & .5 & .5 & 4.6 & 5.8 & .2 & 7.1 & 5.0 & 9.7 & 11.3 & 11.7 & 13 & 14 & 15 \\
\hline
\end{tabular}

All-period consist of 10.5, 11.5, 12.5, 13.5, 15.5, $17.5 \mathrm{dpc}$, neonate, 5 -week-old and adult.

include all samples to reduce variability between experiments. To evaluate the stability of candidate reference genes, commonly used algorithms geNorm, NormFinder, and BestKeeper were used according to the developer's instructions.

Fifteen genes from different pathways were used as candidate genes (Table 1). We used such a large number because when the number of candidate genes is small, correlation may occur even if the expression of two or three genes simultaneously changes. To avoid this problem, many previous reports have used 8 to 15 primers $[7,10,12,14,17,25]$. If multiple genes in the same pathway are used, correlation occurs between the candidate genes [11]. Therefore, in the selection of candidate genes, genes were selected from different pathways with reference to the Mouse Housekeeping Gene Primer Set (Takara Bio), TaqMan Human Endogenous Control Plate (Thermo Fisher Scientific, Waltham, MA, U.S.A.), and previous reports [9, 14, 17, 22, 24, 25].

The samples were assigned to one of three periods according to developmental stage: a sex determination period (10.5$12.5 \mathrm{dpc}$ ), a sex differentiation period (13.5-18.5 dpc), and a postnatal period (neonate, 5-week-olds, and adults) (Tables 2-4). The postnatal period should be divided into before and after puberty, but since there are only three time points, they were combined under "postnatal". In addition, the sex differentiation period included six time points, but the sex determination period and the postnatal period each have only three time points (Table 4). In order to avoid an imbalance toward the sex differentiation period, half of the samples in the sex differentiation period were used for the all-period and fetal-period analyses (Tables 2-4).

The results of the calculation of candidate gene stability in the all-period analysis by the three algorithms are shown in Table 2. The order of reference genes by each algorithm was calculated. We then obtained the geometric mean of those ranks and made it the final rank (Table 2). Simply calculating the mean of the rank despite the existence of different judgment criteria in each algorithm is criticized as not being a scientific method [6]. However, it is impossible to uniformly decide which is better, because each algorithm has advantages and disadvantages [6, 11]. Among the 45 ranks calculated by each algorithm, there were 3 items with rank-order fluctuations of 3, 5 items with fluctuations of 2, and more than half were the same as the mean value (Table 2). This is why we think it is useful to use mean values as rough indicators to select reference genes. Interestingly, genes with a rank of less than 1/3 were common to each algorithm. Even simply excluding these unstable genes from the reference genes will stabilize gene expression analysis experiments.

Several periods commonly used for gonadal sex determination and sexual differentiation studies were analyzed, such as 10.5 to $12.5 \mathrm{dpc}$ and 10.5 to $14.5 \mathrm{dpc}$. As a result, the expression of peptidylprolyl isomerase A (Ppia) and polymerase (RNA) II (DNA directed) polypeptide A (Polr $2 a$ ) was stable under many conditions, especially after $12.5 \mathrm{dpc}$, but the expression of tyrosine 3-monooxygenase/tryptophan 5-monooxygenase activation protein, zeta polypeptide (Ywhaz) and Gapdh was always unstable, and that of Rn18s, Actb, and succinate dehydrogenase complex, subunit A, flavoprotein (Fp) (Sdha) was also unstable in many cases (Table 3). The sexually dimorphic expression pattern was confirmed. That is, although ribosomal protein, large P0 (Rplp0) and beta-2 microglobulin $(B 2 m)$ were stable in males, TATA box binding protein (Tbp), glucuronidase, beta (Gusb), and ubiquitin C $(U b c)$ were stable in females.

As described later, in the period of 10.5 to $12.5 \mathrm{dpc}$, the stably expressed genes were largely different from those in the other periods. The stability of Gusb and Ubc was high, but that of Ppia and Polr2a was relatively low. Notably, stable expression of $S d h a$ was observed, especially in males. Furthermore, the expression of Gusb and $U b c$ after 13.5 dpc became more unstable in males than in females (Table 3). Rn18s, ribosomal protein S29 (Rsp29), Tbp, and Sdha are recommended for gene expression analysis ranging from 11.5 to $14.5 \mathrm{dpc}$ [17], but this result is different from ours. This may be due to differences in calculation algorithms, differences in samples, differences in candidate genes, or differences in mouse strain. In the period of 11.5 to 14.5 dpc, the stability of the candidate gene is relatively high, and it can be used even with the low-rank Rn18s. Particularly in females, the expression of most genes other than Gapdh and Ywhaz was stable. However, the use of a more stable reference gene enables highprecision measurement, so it is better to use Gusb, Ppia, and Tbp during this period.

In the postnatal period, hypoxanthine guanine phosphoribosyl transferase (Hprt), Ppia, and phosphoglycerate kinase 1 (Pgkl) were calculated to be stable, but Hprt and $P g k 1$ were relatively unstable in males compared to females. When we analyzed only males, Ppia, Rplp0, B2m, and Tfrc were stable and Actb, Sdha, Gapdh, and Ywhaz were unstable (Table 3). In the report that evaluated 11 time points from male mice after birth using six genes, Ppia, Gapdh, and Actb were very stable and Hprt and Tbp were unstable [8]. Since Gapdh and Actb are always unstable in our study and are not recommended for studies in adult human testicular cells [16], it is unknown whether these genes are stable. These differences may be primarily caused by differences in the number of candidate genes evaluated. 


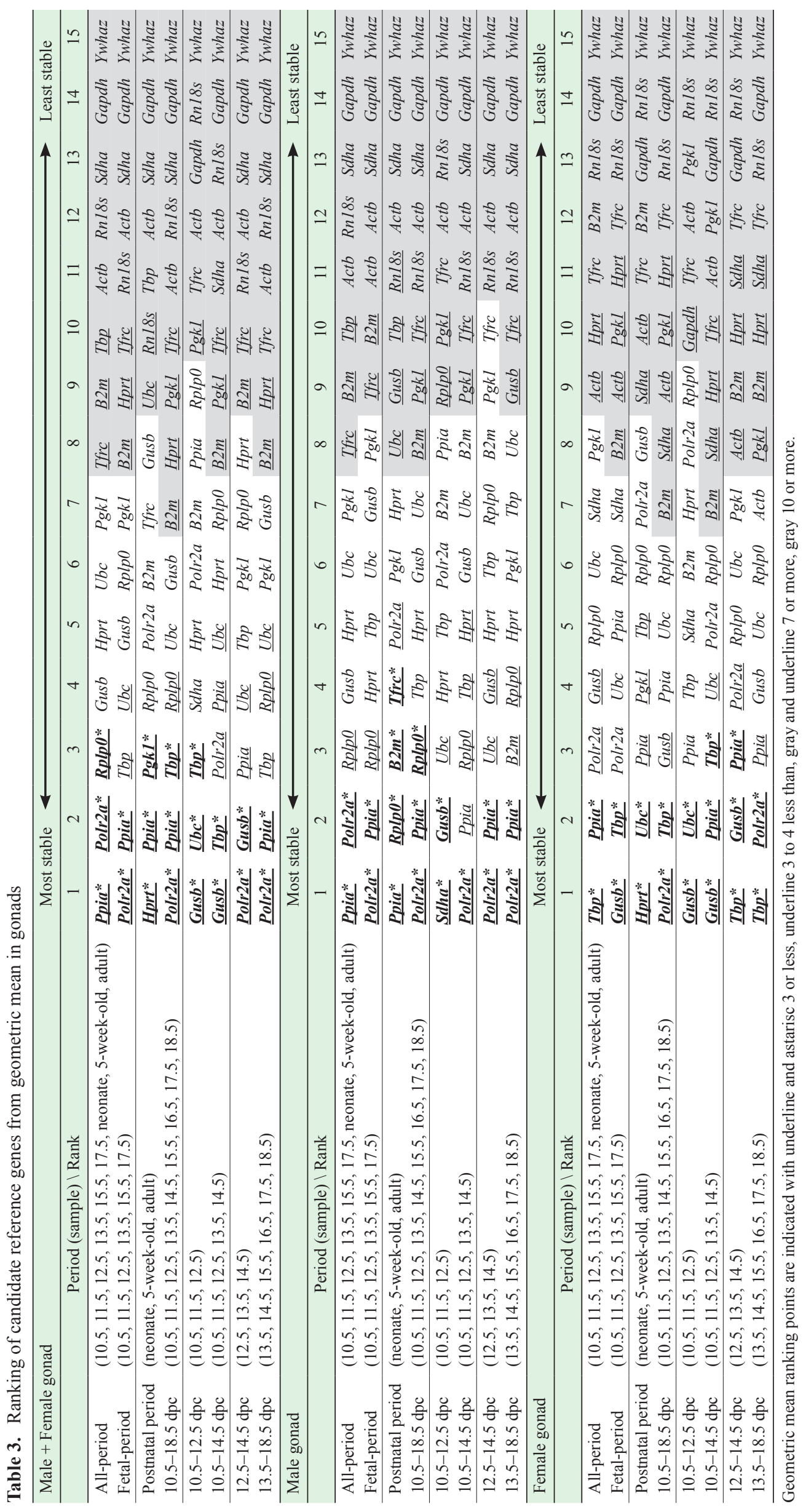


Table 4. Selected reference genes in each stages

\begin{tabular}{|c|c|}
\hline \multicolumn{2}{|c|}{ All-period $(10.5,11.5,12.5,13.5,15.5,17.5$, neonate, 5 -week-old, adult) } \\
\hline Male+Female & Ppia, $\underline{\text { Polr2a }}, \underline{\text { Rplp0 }}$ \\
\hline Male & Ppia, $\underline{\text { Polr } 2 a}$, Rplp0 \\
\hline Female & Tbp, Ppia, Polr2a, Gusb \\
\hline \multicolumn{2}{|c|}{$10.5-18.5 \mathrm{dpc}(10.5,11.5,12.5,13.5,14.5,15.5,16.5,17.5,18.5)$} \\
\hline Male+Female & Polr2a, Ppia, Tbp, Rplp0 \\
\hline Male & $\underline{\text { Polr } 2 a}, \underline{\text { Ppia }}, \underline{\text { RplpO }}$ \\
\hline Female & $\underline{\text { Polr } 2 a}, \underline{\text { Tbp }}$, Gusb \\
\hline \multicolumn{2}{|c|}{ Sex determination period $(10.5,11.5,12.5)$} \\
\hline Male+Female & Gusb, $\underline{U b c}, \underline{T b p}$ \\
\hline Male & $\underline{S d h a}, \underline{G u s b}, U b c$ \\
\hline Female & $\overline{G u s b}, \underline{\underline{U b c}}$ \\
\hline \multicolumn{2}{|c|}{ Sex differentiation period $(13.5,14.5,15.5,16.5,17.5,18.5)$} \\
\hline Male+Female & Polr2a, Ppia, Tbp \\
\hline Male & Polr2a, Ppia, B2m, Rplp0 \\
\hline Female & $\underline{\text { Tbp }}, \underline{\text { Polr2a }}$, Ppia \\
\hline \multicolumn{2}{|c|}{ Postnatal period (neonate, 5 -week-old, adult) } \\
\hline Male+Female & Hprt, Ppia, Pgk1 \\
\hline Male & Ppia, $\underline{\text { Rplp0 }}, \underline{B 2 m}, \underline{\text { Tfrc }}$, Polr $2 a$ \\
\hline Female & $\underline{H p r t}, \underline{U b c}$, Ppia, Pgkl, Tbp \\
\hline
\end{tabular}

Geometric mean ranking points are indicated with underline 3 or less.

In our results, the ranking of recommended reference genes changed greatly depending on gender, developmental stage, and analysis period (Table 3). In particular, when we analyzed only a specific gender in a limited time period, it became clear that highly accurate measurement is possible by using a specific reference gene specialized for experiments (Table 4). In the developmental process of the gonads, the cell type, the number of cells, and the composition ratio contained in the gonad all change with time, and accordingly the expression of many genes, including the reference gene, changes greatly [8, 15, 17]. Because of the high risk of normalization with a single reference gene, it is recommended that multiple reference genes from different pathways be used $[1,11]$.

In this study, we ranked the stability of reference genes according to developmental stage and/or gender. This is very useful for selecting reference genes in gene expression analyses such as quantitative PCR in developing mouse gonads.

ACKNOWLEDGMENTS. This work was supported by Grants-in-Aid for Scientific Research (Nos. 24590401 and 16 K08072 to N. Hoshi and Nos. 26460410 and 17K08686 to T. Yokoyama) from the Ministry of Education, Culture, Sports, Science, and Technology of Japan.

\section{REFERENCES}

1. Abdel Nour, A. M., Azhar, E., Damanhouri, G. and Bustin, S. A. 2014. Five years MIQE guidelines: the case of the Arabian countries. PLoS One 9: e88266. [Medline] [CrossRef]

2. Andersen, C. L., Jensen, J. L. and Ørntoft, T. F. 2004. Normalization of real-time quantitative reverse transcription-PCR data: a model-based variance estimation approach to identify genes suited for normalization, applied to bladder and colon cancer data sets. Cancer Res. 64: 5245-5250. [Medline] [CrossRef]

3. Axtner, J. and Sommer, S. 2009. Validation of internal reference genes for quantitative real-time PCR in a non-model organism, the yellow-necked mouse, Apodemus flavicollis. BMC Res. Notes 2: 264. [Medline] [CrossRef]

4. Bustin, S. A., Benes, V., Garson, J. A., Hellemans, J., Huggett, J., Kubista, M., Mueller, R., Nolan, T., Pfaffl, M. W., Shipley, G. L.,

Vandesompele, J. and Wittwer, C. T. 2009. The MIQE guidelines: minimum information for publication of quantitative real-time PCR experiments. Clin. Chem. 55: 611-622. [Medline] [CrossRef]

5. Chechi, K., Gelinas, Y., Mathieu, P., Deshaies, Y. and Richard, D. 2012. Validation of reference genes for the relative quantification of gene expression in human epicardial adipose tissue. PLoS One 7: e32265. [Medline] [CrossRef]

6. De Spiegelaere, W., Dern-Wieloch, J., Weigel, R., Schumacher, V., Schorle, H., Nettersheim, D., Bergmann, M., Brehm, R., Kliesch, S., Vandekerckhove, L. and Fink, C. 2015. Reference gene validation for RT-qPCR, a note on different available software packages. PLoS One 10: e0122515. [Medline] [CrossRef]

7. Everaert, B. R., Boulet, G. A., Timmermans, J. P. and Vrints, C. J. 2011. Importance of suitable reference gene selection for quantitative real-time PCR: special reference to mouse myocardial infarction studies. PLoS One 6: e23793. [Medline] [CrossRef]

8. Gong, Z. K., Wang, S. J., Huang, Y. Q., Zhao, R. Q., Zhu, Q. F. and Lin, W. Z. 2014. Identification and validation of suitable reference genes for RT-qPCR analysis in mouse testis development. Mol. Genet. Genomics 289: 1157-1169. [Medline] [CrossRef]

9. Han, L. Q., Yang, G. Y., Zhu, H. S., Wang, Y. Y., Wang, L. F., Guo, Y. J., Lu, W. F., Li, H. J. and Wang, Y. L. 2010. Selection and use of reference 
genes in mouse mammary glands. Genet. Mol. Res. 9: 449-456. [Medline] [CrossRef]

10. Kosir, R., Acimovic, J., Golicnik, M., Perse, M., Majdic, G., Fink, M. and Rozman, D. 2010. Determination of reference genes for circadian studies in different tissues and mouse strains. BMC Mol. Biol. 11: 60. [Medline] [CrossRef]

11. Kozera, B. and Rapacz, M. 2013. Reference genes in real-time PCR. J. Appl. Genet. 54: 391-406. [Medline] [CrossRef]

12. Mamo, S., Gal, A. B., Bodo, S. and Dinnyes, A. 2007. Quantitative evaluation and selection of reference genes in mouse oocytes and embryos cultured in vivo and in vitro. BMC Dev. Biol. 7: 14. [Medline] [CrossRef]

13. Pfaffl, M. W., Tichopad, A., Prgomet, C. and Neuvians, T. P. 2004. Determination of stable housekeeping genes, differentially regulated target genes and sample integrity: BestKeeper--Excel-based tool using pair-wise correlations. Biotechnol. Lett. 26: 509-515. [Medline] [CrossRef]

14. Shi, G., Zhang, Z., Feng, D., Xu, Y., Lu, Y., Wang, J., Jiang, J., Zhang, Z., Li, X. and Ning, G. 2010. Selection of reference genes for quantitative real-time reverse transcription-polymerase chain reaction in concanavalin A-induced hepatitis model. Anal. Biochem. 401: 81-90. [Medline] [CrossRef]

15. Svingen, T. and Koopman, P. 2013. Building the mammalian testis: origins, differentiation, and assembly of the component cell populations. Genes Dev. 27: 2409-2426. [Medline] [CrossRef]

16. Svingen, T., Jørgensen, A. and Rajpert-De Meyts, E. 2014. Validation of endogenous normalizing genes for expression analyses in adult human testis and germ cell neoplasms. Mol. Hum. Reprod. 20: 709-718. [Medline] [CrossRef]

17. Svingen, T., Spiller, C. M., Kashimada, K., Harley, V. R. and Koopman, P. 2009. Identification of suitable normalizing genes for quantitative realtime RT-PCR analysis of gene expression in fetal mouse gonads. Sex Dev. 3: 194-204. [Medline] [CrossRef]

18. Taki, F. A. and Zhang, B. 2013. Determination of reliable reference genes for multi-generational gene expression analysis on C. elegans exposed to abused drug nicotine. Psychopharmacology (Berl.) 230: 77-88. [Medline] [CrossRef]

19. Tricarico, C., Pinzani, P., Bianchi, S., Paglierani, M., Distante, V., Pazzagli, M., Bustin, S. A. and Orlando, C. 2002. Quantitative real-time reverse transcription polymerase chain reaction: normalization to rRNA or single housekeeping genes is inappropriate for human tissue biopsies. Anal. Biochem. 309: 293-300. [Medline] [CrossRef]

20. Umemura, Y., Miyamoto, R., Hashimoto, R., Kinoshita, K., Omotehara, T., Nagahara, D., Hirano, T., Kubota, N., Minami, K., Yanai, S., Masuda, N., Yuasa, H., Mantani, Y., Matsuo, E., Yokoyama, T., Kitagawa, H. and Hoshi, N. 2016. Ontogenic and morphological study of gonadal formation in genetically-modified sex reversal XY ${ }^{\mathrm{POS}}$ mice. J. Vet. Med. Sci. 77: 1587-1598. [Medline] [CrossRef]

21. Vandesompele, J., De Preter, K., Pattyn, I., Poppe, B., Van Roy, N. De Paepe, A. and Speleman, F. 2002. Accurate normalization of real-time quantitative RT-PCR data by geometric averaging of multiple internal control genes. Genome Biol. 3: research0034.

22. Veazey, K. J. and Golding, M. C. 2011. Selection of stable reference genes for quantitative rt-PCR comparisons of mouse embryonic and extraembryonic stem cells. PLoS One 6: e27592. [Medline] [CrossRef]

23. Weyrich, A., Axtner, J. and Sommer, S. 2010. Selection and validation of reference genes for real-time RT-PCR studies in the non-model species Delomys sublineatus, an endemic Brazilian rodent. Biochem. Biophys. Res. Commun. 392: 145-149. [Medline] [CrossRef]

24. Willems, E., Mateizel, I., Kemp, C., Cauffman, G., Sermon, K. and Leyns, L. 2006. Selection of reference genes in mouse embryos and in differentiating human and mouse ES cells. Int. J. Dev. Biol. 50: 627-635. [Medline] [CrossRef]

25. Xu, L., Ma, X., Cui, B., Li, X., Ning, G. and Wang, S. 2011. Selection of reference genes for qRT-PCR in high fat diet-induced hepatic steatosis mice model. Mol. Biotechnol. 48: 255-262. [Medline] [CrossRef] 